\title{
Malaysia's Multidimensional Efforts to Implement New Innovation Paradigms
}

\author{
Noor Rizawati Nasir, Mustafa Din Subari
}

\begin{abstract}
Malaysia is one of the developing countries which has the fastest growth rate. It is in its last miles to achieve its goal to become a high-income advanced nation by 2020. The country has enormously reduced its poverty rate and curtailed its inequality gap shaped by various policies and initiatives. With the rate of the poor is now less than one percent, the focus has reoriented to elevate the bottom 40 percent (B40) households to middle-income households. Various initiatives have been strategised to address the $B 40$ which also include innovation initiatives that are aimed at addressing the marginalised in Malaysia. The initiatives seek to provide the marginalised with better access to services and products and job opportunities by empowering them to contribute to society. Hence, this paper seeks to take stock the government policy measures as well as the initiatives by reviewing the relevant documents. The findings show that the existing government innovation efforts are aligned with the national and global agenda on sustainable development, where inclusivity and sustainability remain as its main agenda. The authors proposed an integrated framework of implementation to serve as a tool to guide policymakers for better implementation in the future.
\end{abstract}

Keywords: Innovation, policy, Malaysia, new innovation paradigms.

\section{INTRODUCTION}

Malaysia previously was a country that heavily relied on primary commodities as the main economic contributor. After the Independence in 1957, the country has successfully lifted itself from a poor country and becomes a middle-income country [1]. The country recognises innovation an important key driver to growth where the performances can be seen in various areas such as the increase in investment in research and development (R\&D), a growing number of researcher per 10,000 labour force [2] and improved performance in several innovation pillars reported in the Global Index Innovation 2019 [3]. The gross domestic product (GDP) and productivity performances demonstrate that the country's commitment is on the right track in achieving its aspiration of becoming a high-income advanced economy. However, the performances do not necessarily translate to equal economic benefits where the impact might be adversely affecting the most vulnerable group. In this respect, the country also committed to achieving the 2030 Agenda of Sustainable Development with inclusive growth and sustainable development are the fundamentals in the development of its policies and plans. This indicates whilst the effort to gain better economic

Revised Manuscript Received on September 14, 2019.

Noor Rizawati Nasir, Razak Faculty of Technology and Informatics, Universiti Teknologi Malaysia, Kuala Lumpur, Malaysia. (Email: nrizawati2@live.utm.my)

Mustafa Din Subari, Razak Faculty of Technology and Informatics, Universiti Teknologi Malaysia, Kuala Lumpur, Malaysia. (Email: m.subari@utm.my.) performance and sustain its growth momentum, it does not compromise the needs of the people to attain equal benefits from growth.

Notwithstanding, the effort to deal with the poverty issue is a challenging task where there are still poor people in the areas that have limited access to services and job opportunities [4]. Despite the socio-economic improvement, there are still among the poor are at risk of economic shock [5]. The disparity between the top 20 percent income group and the B40 is enlarging [6]. Issues that are associated with the B40 are their limited capacity and capability; low level of wealth possession and the rising living cost [7]. The failure to tackle this group will eventually lead to additional social costs and limits the country capacity to grow and the B40 may be left out of the mainstream development. In this regard, aligned with the government goals to enhance its economic growth and social well-being, the Eleventh Malaysia Plan (11MP) places a high priority on increasing the well-being and income of the B40. The country has come up with more measures to cater to the needs of the B40 in the recent Mid Term Review (MTR) of 11MP. To ensure inclusivity, the plan highlights, among others, increasing the income and purchasing power of the B40 households; empowering minority groups; and meeting the needs of specific target groups [7].

The government is mindful that in dealing with multiple challenges amidst the fast-changing socio-economic environment, there is the need to shift from the traditional approaches of implementation for outcome optimisation. Hence, other than relying on traditional approaches to social service delivery, one way to achieve the inclusivity and sustainability goals in implementation is through the optimisation of science, technology and innovation (STI) full potential as the solutions to innovatively address social needs and achieve long term socio-economic goals. In this regard, several measures have been introduced. As a result, several initiatives have been initiated to align with stipulated measures. Hence, this paper seeks to stock take the existing policy measures and initiatives that promote new innovations paradigms in Malaysia.

This paper is divided into four sections. Section 1 provides a review of the literature with regards to the topic. Section two discusses specifically on innovation agenda in Malaysia focusing on policy measures on social agenda. Section three offers a discussion on policy implication and recommendation. Finally, section four concludes the study. 


\section{LITERATURE REVIEW}

Innovation is known for its vital role in enhancing social well-being and economic performance. The OECD Oslo/Eurostat Manual defines innovation as the implementation of a new or significantly improved product (good or service), or process, a new marketing method, or a new organisational method in business practices, workplace organisation or external relations" [8]. Innovation can derive from various forms, for instance, product innovations, process innovations, marketing innovations and managerial and organisational innovations [9].

Although, in the context of the usage of the term, it is common that the term associated with economic and technological innovation. It is frequently conceived as relating to the commercialisation of an idea [10] with less attention to its potential in solving the social issue as compared to the market-driven technical issues [11]. With respect to innovation discourse, the traditional, establishment players in industry, academia and government are normally the focus [10]. These thoughts signify that there is a limited comprehension of the potential contribution of innovation for social issues.

The scholars have pointed out that though the STI activities have contributed to the transformation in economic growth through breakthrough technological innovations, it actually has both inclusionary and exclusionary outcomes [12]. The existing format on policies of innovation, whilst it promotes growth, also resulted in the inequality incidences [13]. This indicates that there is the disconnection of innovation that focuses more on economic growth and social aspect of it, where they appeared to be poorly fit.

In fact, innovation can go beyond that. Innovation can be also referred to qualitative innovations, sustainable development approaches, new material processes and usage as well as production methods, optimisation, new ecologically friendly processes and methods, which in exchange they actively lead to sustainable development goals, effectively [14]. Given the current wave of global change, people with skills and entrepreneurial capabilities have better opportunities to participate in innovation activities. Whilst, others who have the lack of these, having fewer opportunities to participate and benefit equally. Responding to this, various new innovations paradigms have been introduced to promote innovation activities among the people through the exploitation of new and improved ideas that can solve pressing issues facing the government and society. The innovations are known as social innovation, grassroots innovation, inclusive innovation, pro-poor innovation and grassroots innovation. These new innovation paradigms are different from the traditional model of innovation where the emphasis is given more on benefitting the society fairly, notwithstanding different approaches of implementation. Among the globally known efforts includes microfinance - the provision to support those who are lowincome with the lack of access to financial services for them to gain such access that will help them to lift themselves from poor status; fair trade - market based approach aimed at assisting developing countries' producers and fostering sustainability by working with the marginalised producers to support them to become economically stable and selfsufficient [15]; and open-source software - encourage open distribution of source code and collaborative software authoring that is then disseminated at no cost to others [16].

Many countries have started to embed these new innovation paradigms into their policies and plans with a variety of initiatives inter alia the provisions of grants for various actors including the local innovators to contribute to society either socially or economically. Malaysia also displays its support to promote these new innovation paradigms as stipulated in its policies and plans.

\section{INNOVATION AGENDA IN MALAYSIA}

Comprehending the pivotal role of innovation in driving social and economic growth of the nation, Malaysia has started to prioritise its national agenda by integrating innovation as one of the main themes in its national economic model [17]. During the Tenth Malaysia Plan (10MP), innovative activities were promoted across the Malaysian economy [18]. Later, in the 11MP, in its quest to align with the Agenda 2030 of Sustainable Development and achieve its main pledge of 'no one left behind', Malaysia has committed itself to implement initiatives to achieve the goals set manifested in various policies and plans. The government has set innovation as one of the game changers with achieving social agenda through social innovation is highlighted as one of the strategies [19]. 
Table- I: Brief of information on the initiatives by ministry and agencies

\begin{tabular}{|c|c|c|c|c|}
\hline Ministry/Agencies & Programme & Grant Beneficiary & Objective & Priority Area/Theme \\
\hline MESTECC & $\begin{array}{l}\text { CIF (Under } \\
\text { Innofund) }\end{array}$ & $\begin{array}{ll}\text { - } & \text { Registered Associations/ } \\
\text { NGOs } \\
\text { - } \text { Registered Cooperatives } \\
\text { - } \text { Community Group }\end{array}$ & $\begin{array}{l}\text { To help the community to turn } \\
\text { knowledge and ideas into products, } \\
\text { processes or services seek to } \\
\text { enhance the community } \\
\text { socioeconomic status and their } \\
\text { quality of life. }\end{array}$ & $\begin{array}{l}\text { - } \text { Life Sciences, } \\
\text { - Computer Sciences and } \\
\text { Information and } \\
\text { Communication } \\
\text { Technology (ICT), } \\
\text { - Agriculture } \\
\text { Sciences/Agricultural } \\
\text { Engineering } \\
\text { - Environmental Sciences, } \\
\text { - Advanced Materials } \\
\text { - Science, } \\
\text { - Chemical Sciences, } \\
\text { - Physical and } \\
\text { Mathematical Sciences, } \\
\text { - Engineering, } \\
\text { - Medical and Health } \\
\text { Sciences, and } \\
\text { - Social Sciences and } \\
\text { Humanities } \\
\end{array}$ \\
\hline MESTECC & MySI & $\begin{array}{l}\text { Government agencies/ } \\
\text { government-linked companies } \\
\text { collaborate with any entities } \\
\text { (government agencies, } \\
\text { registered organisations, } \\
\text { government-linked companies }\end{array}$ & $\begin{array}{l}\text { To apply the locally developed } \\
\text { innovative R\&D technology to } \\
\text { enhance the community's quality } \\
\text { of life, focusing on the B } 40 \text { group, } \\
\text { sustainably }\end{array}$ & $\begin{array}{l}\text { - Economy } \\
\text { - Green technology } \\
\text { - Environmentally } \\
\text { friendly } \\
\text { - Healthcare } \\
\text { - Security } \\
\end{array}$ \\
\hline MaGIC & $\begin{array}{l}\text { Social } \\
\text { Entrepreneurship } \\
\text { Bootcamp }\end{array}$ & $\begin{array}{l}\text { - Early Stage Start-up } \\
\text { - Corporate Entrepreneurs } \\
\text { - Working Professionals } \\
\text { - Graduates and Final Year } \\
\text { Students }\end{array}$ & $\begin{array}{l}\text { A programme that offers } \\
\text { opportunities for early-stage Social } \\
\text { Enterprises and innovators to pilot } \\
\text { their idea, test business plans, } \\
\text { strengthen impact delivery models } \\
\text { and secure investment via } \\
\text { innovative entrepreneurship } \\
\text { strategies. }\end{array}$ & $\begin{array}{l}\text { Employment for } \\
\text { marginalised } \\
\text { - } \text { Equality \& } \\
\text { empowerment } \\
\text { - } \text { Pollution \& Waste } \\
\text { Management } \\
\text { - Income/Productivity } \\
\text { Growth } \\
\text { - Community } \\
\text { Development } \\
\end{array}$ \\
\hline MaGIC & Youth Co: Lab & Youth innovators & $\begin{array}{l}\text { 3-day bootcamp series to incite, } \\
\text { catalyse, and sustain youth } \\
\text { innovation, aiming at creating a } \\
\text { positive impact on some of the } \\
\text { most demanding issues facing the } \\
\text { nation. }\end{array}$ & $\begin{array}{l}\text { - Energy Efficiency and } \\
\text { Environmental } \\
\text { Sustainability } \\
\text { - Financial Inclusion } \\
\text { - Income Generation for } \\
\text { Undocumented Persons } \\
\end{array}$ \\
\hline MaGIC & $\begin{array}{c}\text { Social } \\
\text { Entrepreneurship } \\
\text { (SE) Masterclass }\end{array}$ & $\begin{array}{l}\text { - Social Entrepreneurs } \\
\text { - Social Enterprises } \\
\text { - Start-ups with social impact } \\
\text { - MSMEs with social impact } \\
\text { - NGOs } \\
\text { - Students } \\
\text { (Undergraduates/Postgradua } \\
\text { tes) } \\
\end{array}$ & $\begin{array}{l}\text { 1-day course for aspiring and } \\
\text { early-stage social enterprises with } \\
\text { thorough immersion of social } \\
\text { entrepreneurship essentials to help } \\
\text { develop or validate social impact } \\
\text { ideas. }\end{array}$ & Not available \\
\hline $\begin{array}{l}\text { MaGIC and } \\
\text { myHarapan }\end{array}$ & $\begin{array}{l}\text { Pemangkin } \\
\text { Usahawan } \\
\text { Sosial Hebat } \\
\text { (PUSH) }\end{array}$ & $\begin{array}{ll}\text { - } & \text { B40 (as an apprentice) } \\
\text { - } & \text { Enterprises (Impact Driven } \\
& \text { Enterprise) }\end{array}$ & $\begin{array}{l}\text { Seeks to promote positive social } \\
\text { impact and inclusive business } \\
\text { through the development of micro- } \\
\text { entrepreneurship opportunities. }\end{array}$ & Not available \\
\hline $\begin{array}{l}\text { MaGIC and } \\
\text { myHarapan }\end{array}$ & $\begin{array}{c}\text { Social Enterprise } \\
\text { Ventures }\end{array}$ & Social enterprises & $\begin{array}{l}\text { A partnership between MaGIC and } \\
\text { MyHarapan to fund scalable and } \\
\text { sustainable youth-driven social } \\
\text { projects. The fund is a pilot fund } \\
\text { for IMPACT for those who intend } \\
\text { to franchise their business to the } \\
\text { B40 beneficiaries communities. }\end{array}$ & Not available \\
\hline YIM & MaGRIS & Grassroots innovators & $\begin{array}{l}\text { To enhance and drive the efforts to } \\
\text { develop potential grassroots } \\
\text { innovations through a partnership } \\
\text { with multiple stakeholders } \\
\text { including providing them with } \\
\text { capacity building. }\end{array}$ & Not available \\
\hline
\end{tabular}




\begin{tabular}{|c|c|c|c|c|}
\hline YIM & $\begin{array}{l}\text { Inclusive } \\
\text { Innovation } \\
\text { (HIP6) }\end{array}$ & Micro-enterprises & $\begin{array}{l}\text { To empower communities } \\
\text { including microenterprises and the } \\
\text { B40 to leverage innovation in the } \\
\text { rural areas via support in terms of } \\
\text { the handhold, financial, technical } \\
\text { and management }\end{array}$ & $\begin{array}{l}\text { - Utility } \\
\text { - Healthcare } \\
\text { - Education } \\
\text { - } \text { Productivity }\end{array}$ \\
\hline AIM & SOF & Social Purpose organisations & $\begin{array}{l}\text { Funds for innovative social } \\
\text { interventions by the Social } \\
\text { Purposes Organisations in } \\
\text { addressing social issues that utilise } \\
\text { pay for success model reimbursed } \\
\text { to the third-party funder. }\end{array}$ & $\begin{array}{l}7 \text { social issues related to: } \\
\text { - Abuse } \\
\text { - Crime } \\
\text { - Employment } \\
\text { - Living conditions } \\
\text { - Vice } \\
\text { - Education } \\
\text { - Healthcare }\end{array}$ \\
\hline AIM & $\begin{array}{l}\text { Social Impact } \\
\text { Exchange }\end{array}$ & Social Purpose organisations & $\begin{array}{l}\text { A platform for social purpose } \\
\text { organisations or projects with high } \\
\text { social impact and link them with } \\
\text { potential corporates as funders }\end{array}$ & \\
\hline
\end{tabular}

In this regard, the topic of innovation for inclusiveness and sustainability has started to become one of the topics that are increasingly discussed in Malaysia. It has become among one of the emerging topics of discussion in public policy and academic discourse. The needs to have such measures in the public policy were driven by multiple issues that are occurring in Malaysia such as the low economic capacity of the low-income groups as well as limited access to basic necessities in some areas. Following this, the government started to introduce several grants to the wider segment of people in Malaysia not limiting to government entities and private sector but also covers organisations, individuals and grassroots communities to encourage more innovative solutions that can benefits society in terms of social as well as economic well-being via STI as the tool for solutions.

The Ministry of Energy, Science, Technology, Environment and Climate Change (MESTECC) which previously known as the Ministry of Science, Technology and Innovation (MOSTI) outlined social, grassroots and prosumer innovation as one of the policy measures under Strategic Thrust 3: Energising Industry in the National Policy of Science, Technology and Innovation, 2013-2020 (NPSTI) [20]. As the ministry that is mandated to lead the nation's STI agenda, MESTECC started to provide grants to address the marginalised through the implementation of several initiatives. Among the first initiative that was aimed at addressing the community via the application of technologies developed or adopted by MOSTI, known as Technology Application Programme or TAPMOSTI @ Community introduced in 2009 [21]. Then, Community Innovation Fund (CIF) was introduced to help the community to turn knowledge and ideas into products, processes or services to enhance the community socioeconomic status and their quality of life [22]. Another recent programme that was introduced with the aims of improving the well-being of society is MOSTI Social Innovation (MSI). This programme implement projects, services, capacity and skill-building or innovation output via the existing technology [23]. In 2018, MSI has been rebranded with several eligibility criteria were revised and, the fund renamed as Malaysia Social Innovation (MySI). The objective has been changed to the application of the locally developed innovative $R \& D$ technology to enhance the community's quality of life, focusing on the B40 group, sustainably [24].
In a bid to cultivate the awareness of the potential of STI as the tool that can help to enhance people's quality of life, Malaysia Innovation Foundation (Yayasan Inovasi Malaysia - YIM) was founded in 2008. As an innovation agent, YIM is mandated to implement several activities under the technology facilitation and business innovation; knowledge and resource management and community innovation [25]. Two programmes are implemented under the technology facilitation and business innovation are Mainstreaming Grassroots Innovations (MaGRIS) and Inclusive Innovation under the High Impact Programme 6 (HIP6) [26]. MaGRIS' objective is to enhance and drive the efforts to develop potential grassroots innovations through a partnership with multiple stakeholders including providing them with capacity building [27]. For the HIP6, this programme is a part of High Impact Programmes (HIP) under the SME Master Plan 2012-2020 where YIM was selected by the SME Corp. as the programme implementer. This programme aimed at empowering communities including microenterprises and the B40 to leverage innovation in the rural areas via support in terms of the handhold, financial, technical and management [28]. Under the knowledge and resource management, the activities include innovations repository, research, analysis and knowledge management [29]. Whilst, under the community innovation, YIM provides 'Community Profiling' to fill the gap between decision-makers and innovators in reaping understandings of issues concerning the local community [30].

In 2013, the previous Prime Minister announced the establishment of the Malaysian Global Innovation and Creative Centre (MaGIC). MaGIC is mandated to promote entrepreneurship culture including connecting and fostering collaboration among the entrepreneurs, support for startups, enable mentoring, sharing of expertise and knowledge, and provide available resources to those who intend to commence business in Malaysia [31]. In 2015, MaGIC published Malaysia Social Enterprise Blueprint (MSEB) 2015-2018. This Blueprint outlined three strategic thrusts, which is to say, inspire movement; create an enabling ecosystem; and affect systematic changes [32]. Under MaGIC, various programmes have been put in place including Social Entrepreneurship Bootcamp, Social Entrepreneurship (SE) Masterclass, Pemangkin Usahawan 
Sosial Hebat (PUSH), and Social enterprise Ventures [33]. In the attempt to recognise social enterprises, the Ministry of Entrepreneurship Development (MED) introduced Social Enterprise Accreditation (SEA) which was launched in 2019. With the development of such guidelines, the social enterprises could enjoy multitude forms of assistance as well as tax deduction benefits. This has been set out as the initiative under the social enterprise's priority area in the National Entrepreneurship Policy (Dasar Keusahawanan Negara - DKN) 2030. The policy also outlined strengthening the implementation of social entrepreneurship via the implementation of awareness, support and capacity development programmes for the social enterprises to scale up their market and business sustainability as one of the strategic thrusts [34].

In the most recent Malaysia Plan, namely the $11 \mathrm{MP}$, social innovation framework has been developed to promote the implementation of innovative ways of delivering social services through the collaboration of different parties to optimise the benefits to society [19]. Following this, a study has been conducted, namely Social Progress Assessment (SPA), spearheaded by the Malaysian Innovation Agency (Agensi Inovasi Malaysia - AIM) to prioritise social issues which require the most attention from the government [35]. This study involved several relevant agencies and ministries in which they have contributed valuable inputs where several issues have been identified to be prioritised. To implement the social innovation framework proposed in the $11 \mathrm{MP}$, AIM was mandated to initiate a programme namely Social Public-Private Partnership (SPPP). The programme was carried out based on two focus areas namely, "1) developing a PPP model for social good, and 2) empowering the social sector" [36]. Another programme was also introduced, namely Social Outcome Fund (SOF), where this programme seeks to promote social funding for social intervention programmes from corporates, foundations and individuals [37]. This initiative applies the 'pay for success' model in its implementation where the fund repaid to the investors once the projects implemented by social purpose organisations (SPOs) have successfully achieved the key performance indicators (KPIs) set earlier [38]. AIM is also mandated to implement Social Impact Exchange, a listing platform for SPOs or projects with high social impact for society via social interventions [37]. The detail explanation of the programmes is as shown in Table I.

\section{DISCUSSION \& RESULTS}

Reviews of the literature revealed that there are considerable efforts have been put in place by the government to support such initiatives implemented across ministries and agencies. The perception of STI is not any more associated with breakthrough technological innovations per se, but gradually, the social value of innovation has been recognised and appreciated. This signifies the commitment of the government to pursue economic performance without disregarding the contribution of STI as a tool for sustainable and inclusive growth.

Based on the reviews, it is explicit that the programmes are implemented on the basis of four components namely:

a) Capacity building development and enhancement via skills training, mentoring, knowledge and resource sharing and exposure;

b) Provision of grants to fund the government agencies to use STI as the tools to help local communities to resolve local problems;

c) Provision of direct grants to fund the innovators including organisations to work on projects that can benefit local communities;

d) Support to scale up potential innovators; and

e) Provide platform linking the innovators with the potential funders.

The government's efforts to implement such initiatives by placing the new innovation paradigms among the explicit agenda for socio-economic development appear to be encouraging. The analysis shows that there are efforts have been initiated to cater to the need of growing innovators, starting from awareness and exposure, capacity development, bridging the innovators to potential funders, to upscaling their innovations. Notwithstanding, in some instances, it is observed that there exists some element of redundancy, particularly in terms of themes and priority areas; programme scopes; and grant recipients. Nevertheless, it is noted that these elements are not totally competing. For instance, where the priority areas are the same, but the grant recipients are different. Similarly, in the event that the same grant recipients are eligible, but the scopes of the programmes are different.

Nevertheless, since the principal reason why these new innovation paradigms are introduced, that is to address the issues of the adverse impact of the distribution of economic benefits to the marginalised and financial limitation facing the government, the government should consider looking into eliminating the possible degree of redundancy of its programmes. Programmes that are implemented dispersedly with the lack of direction and competing priorities under the thin available resources might affect government financial sustainability. Simultaneously, this also limits other people to benefit from government programmes equally. Accordingly, there is a need to strengthen and streamline the initiatives for impact optimisation.

To address this, this study proposes an integrated implementation framework that serves as a tool to guide better implementation in future. The framework seeks to ensure that the initiatives work in complementary and not competing under the same ecosystem in which it tries to eliminate the issue of fragmentation of efforts. This will enable well-targeted interventions and systematic investment in the areas that require urgent solutions with end to end facilitation. To this end, the framework is outlined as follows:

a) Focus areas and priority setting - conduct periodic studies to identify areas that need to be prioritised and map complementary but not competing measures to be undertaken to address the issues.

b) Integrated open registry on innovations to assist projects selection, diffusion and scaling up 
c) activities to amplify the impact while ensuring there is no duplication of initiatives that may incur more cost to the government.

d) Indicators and measurement mechanism - to provide evidence-based information for the purpose of assessment, monitoring and evaluation and provisions of incentives and second round of support for potential innovations.

e) Capacity building and enhancement - to provide talents and skills development training and exposure at different phases to equip the beneficiaries, innovators and implementers with skills needed for effective implementation.

f) Shared facilities - leverage existing facilities to enable the innovators to experiment, develop and produce their innovations.Intermediaries - entities that connect the potential innovators with the relevant agencies or private sectors to help them to move forward in terms of scaling up their innovations and deal with various regulatory and procedures.



Fig. 1. Integrated implementation framework

Not only that the framework illustrated in Fig. 1 pursues to reduce the possibilities of the occurrences of overlapping of programmes, it also seeks to reduce a problem called 'valley of death' where survival of innovation to move from one end to the other end serves as the most challenging task [39]. Such practice of one-off interventions, with the lack of end to end supports, can result in the failure to achieve the intended impact towards the society and the potential innovators may become frustrated as they are unable to move forward due to the lack of support needed by them to scale up their innovations which can result in the outflow of innovative talents. Hence, these fundamental elements can serve as a tool of guide for policymakers in analysing and deciding on what or which programmes should be considered.

\section{CONCLUSION}

Innovation is no longer associated with breakthrough technological innovations and cutting-edge technologies that can only benefit those at the high-end economy. The introductions of the new innovation paradigms have successfully helped many people around the world to get access to various necessities and create income opportunities by including the marginalised into the system. Malaysia, a country which is in its final leg to become a developed country, has integrated the new innovation paradigms in its policies and plans with various initiatives have been implemented. Though the efforts are there, there is the need to strengthen and streamline the programmes to eliminate the issue of redundancy towards optimising the impact. Hence, this study proposes an integrated implementation framework that seeks to address the gaps. To this end, the fundamental elements of the framework may serve as the tools to guide the policymakers to analyse and decide on what or which programmes should be considered. This article has several drawbacks in term of the academic references on the implementation of the initiatives of the policies. This is because there is a limited study have been undertaken to delve into the implementation of such initiatives. However, it helps to shed the lights to the policymakers on the current state of new innovation paradigms in Malaysia and what can be done to optimise the implementation.

\section{REFERENCES}

1. Ahmad Ashfaq and AmnaKhatoon (2014).Evaluating toxicological effects, pollution control and wastewater management in pharmaceutical industry. International journal of current research and academicreview.ISSN:2347-3215volume 2 number 7 (2014).

2. AmitKumarTiwariandVijayKumar Upadhyay (2013) 'Fenton's reagent dose calculation with respect to COD value and the process requirement optimization for effective oxidation of Aqueous Molten Liquid Effluent of an API manufacturing industry', International Journal of Advanced Research, volume1, issue7, 158-164.

3. A.M. Deegan,B.Shaik,K.Nolan,K.urell, M.Oelgemoller, J.Tobin,A. Morrissey (2011).Treatment options for wastewater effluents from pharmaceutical companies. Int.J.Environ.Sci.Tech. 8(3), 649-666.

4. ChelliapanS.IandGolarS.(2011)Pre- treatment of Antibiotic Waste water using an Anaerobic Reactor. Research Journal of Chemical Sciences Vol.1 (6), 59-63.

5. .Dr.A. Ried, Dr.J.Mielcke, M.Kampmann (April32006) The right Treatment Step Ozone and Ozone for the degradation of non-biodegradable COD. International Conference Ozone and UV. GomeA and Upadhyay K. (April 2013)Biodegradabilit AssessmentofPharmaceuticalWastewaterTreatedbyOzone .International Research Journal of Environment Sciences. Vol.2 (4), 21-25.

6. Aswini,V.Sridevi,M.P.D.PrasadandA.Vamsikrishna(Octo ber 2014).Treatment of Pharmaceutical Waste Water by Exigency Methods: A Review. Indian Journal of Applied Research.Volume:4issue 10, October2014, issn-2249$555 X$.

7. N.s.Sebastian, Josep Figuls Fernandez, Xavier Font Segura, A.S.Ferrer (2003). Pre- oxidation of Extremely Polluted Industrial Waste water by the Fenton's Reagent JournalofHazardousMaterials.B101315-322.

8. Prashant K.Lalwani, MaluD.Devadasan (May-Jun 2013). Reduction of COD and BOD by Oxidation. A Cetp case study.

9. Slayed Hussein, Shahid Shaikh and Mazahar Farooq (2011). Chemical Oxygen Demand (COD).Reduction of Aqueous Active Pharmaceutical Ingredient ofIsorobide5Mononitrate waste Water streams by Advanced 
Oxidation-Fenton Process based onH2O2/FE+2 Salt. Archives oApplied Science Research, 2011,3(2):169173.

10. Sudhir Kumar Gupta and Sunil Kumar Gupta. Treatment of Pharmaceutical wastes

11. V.C.Renge, Prof.S.V.Khedkar, Miss.KhushabuS. Bhoyar (2012). Micro Pollutant Removal from Waste Water Treatment plant-A review. International Journal of Advanced $\quad$ Engineering Technology IJAET/vol.III/ISSUEIV/oct- dec2012

12. Apambire, W.M., Boyle, D.R., AND Michel, F.A. (1997).Geo chemistry, Genesis and Health Implications of Floriferous Groundwater in the Upper regions of Ghana. Environmental Geology,35(1), 13-24.

13. Appelo and Postma, 1993. Geochemistry, Groundwater and Pollution.

14. BIS (Bureau of Indian Standards) (1992).Indian Standard Specifications for drinking water IS: 10500.

15. Brindha, K.And Elango, L. (2011) Fluoride in Groundwater: causes, Implications and Mitigation Measures. IN: Monroy, S.D. (ED), Fluoride

16. Data, P.S., Deb, D.L., AND Tyagi, S.K.(1996). Stable isotope (180) Investigations on the Process Controlling Fluoride Contamination of Groundwater. Journal 1 of Contaminant Hydrology, 24, 85-96.

17. Dhiman S.D. AND Keshari, A.K.(2006).Hydro geochemical Evaluation of High- Fluoride Ground waters: A Case Study from Mehsana District, Gujarat, INDIA. Hydrological Sciences Journal, 51(6), 11491162.

18. Gupta, s. Mondal and D.Bardhan, a geochemical provenance and spatial distribution of fluoride in groundwater in parts of Raniganj coal field, west Bengal, India. Archives of applied science research,2012, 4(1):292-306

21. World health organization

\section{AUTHORS PROFILE}

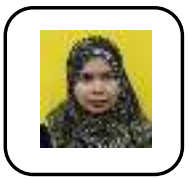

Noor Rizawati Nasir is a PhD student in Perdana Centre of Science, Technology and Innovation Policy, Razak Faculty of Technology and Informatics, Universiti Teknologi Malaysia. She is a also a government servant and has been serving the government of Malaysia for about 13 years. Academically, she holds a bachelor's degree in Human Sciences majoring in Psychology and master's degree in Public Administration from International Islamic University Malaysia and Universiti Sains Malaysia, respectively. She is currently pursuing her research in policy studies, focusing on the implementation of science, technology and innovation policy in addressing the low-income households in Malaysia.

Mustafa Din Subari is a Professor in Razak Faculty of Technology and Informatics. His highest academic qualification is $\mathrm{PhD}$ in GPS Surveying obtained from University of New South Wales, Sydney, Australia. He also holds M.Sc. in Geodetic Sciences from the Ohio State University and B. Survey in Land Survey (Hons) from Universiti Teknologi Malaysia. His areas of expertise cover Space Policy, Space Act, Satellite System, Global Navigation Satellite System (GNSS), Positional Astronomy \& Falak Syar'ie. He also has professional membership, namely as an academic member of International Academy of Aeronautics, a founding member of Malaysian Society for Engineering and Technologist, and Persatuan Falak Syar'ie Malaysia. 